\title{
Synthesis and reactivity of cyclopentadienyl chloro, imido and alkylidene tungsten (VI) complexes
}

\author{
F. Javier de la Mata, Javier Gómez, Pascual Royo * \\ Departamento de Química Inorgánica, Universidad de Alcalá, Campus Universitario, E-28871 Alcalá de Henares, Spain
}

\begin{abstract}
This paper describes the synthesis and characterization of alkylidene pentamethylcyclopentadienyl imido tungsten(VI) complexes via $\alpha$-hydrogen abstraction processes from suitable alkyl derivatives. Reaction of $\mathrm{WCp}^{*} \mathrm{Cl}_{4}$ with one equivalent of $\mathrm{NH}_{2} \mathrm{R}$ $\left(\mathrm{R}={ }^{\mathrm{t}} \mathrm{Bu}, 2,6-\mathrm{Me}_{2}-\mathrm{C}_{6} \mathrm{H}_{3}\right)$, two equivalents of $\mathrm{NEt}_{3}$ and subsequent oxidation with $\mathrm{PCl}_{5}$ affords the pentamethylcyclopentadienyl imido tungsten derivatives, $\mathrm{WCp} *\left(\mathrm{~N}^{\mathrm{t}} \mathrm{Bu}\right) \mathrm{Cl}_{3} 2$ and $\mathrm{WCp}^{*}\left(N-2,6-\left(\mathrm{Me}_{2}\right)-\mathrm{C}_{6} \mathrm{H}_{3}\right) \mathrm{Cl}_{3}$ 4. Alkylation of complexes 2 and 4 with 1.5 equivalents of $\mathrm{ZnMe}_{2}$ under appropriate conditions yields the trimethyl derivatives WCp* $\left(\mathrm{N}^{t} \mathrm{Bu}\right) \mathrm{Me}_{3} \mathbf{5}$ and WCp$*\left(N-2,6-\left(\mathrm{Me}_{2}\right)-\right.$ $\left.\mathrm{C}_{6} \mathrm{H}_{3}\right) \mathrm{Me}_{3}$ 6. Exposure of complex 6 to sun-light leads to the formation of WCp* $\left(N-2,6-\left(\mathrm{Me}_{2}\right)-\mathrm{C}_{6} \mathrm{H}_{3}\right)\left(=\mathrm{CH}_{2}\right) \mathrm{Me} 7$ through a $\alpha$-hydrogen abstraction process. Analogously, complex 2 reacts with 1.5 equivalents of $\mathrm{Mg}\left(\mathrm{CH}_{2} \mathrm{Ph}\right)-(\mathrm{thf})_{2}$ or three equivalents of $\mathrm{LiCH}_{2} \mathrm{SiMe}_{3}$ to give the alkylidene complexes, WCp* $\left(\mathrm{N}^{\mathrm{t}} \mathrm{Bu}\right)(=\mathrm{CHPh})\left(\mathrm{CH}_{2} \mathrm{Ph}\right) \mathbf{8}$ and $\mathrm{WCp}^{*}\left(\mathrm{~N}^{t} \mathrm{Bu}\right)(=\mathrm{CHSiMe} 3) \mathrm{Cl} \mathbf{9}$, through a spontaneous $\alpha$-hydrogen abstraction process in these cases. (C) 1998 Elsevier Science S.A. All rights reserved.
\end{abstract}

Keywords: Alkyl; Alkylidene; Cyclopentadienyl; Imido; Tungsten

\section{Introduction}

The chemistry of transition-metal imido complexes [1] has been widely encountered throughout the literature in recent years, especially for their role as reactive intermediates in industrial [2] and laboratory organic syntheses [3]. Several $\eta^{5}$-cyclopentadienyl imido complexes of group VI metals have been reported lately using several synthetic procedures [4]. Recently, our research group has reported alternative methods for the preparation of mononuclear cyclopentadienyl and cyclopentadienyl imido derivatives of molybdenum and tungsten in high yields [5].

There has also been considerable interest in the chemistry of high-valent tungsten imido alkylidene complexes because these complexes are among the most effective early-transition-metal metathesis catalysts synthesized to date [6]. Recently, new types of metal alkylidene compounds have been reported by Boncella and

\footnotetext{
* Corresponding author. Tel.: + 341 8854765; fax: + 3418854683 ; e-mail:proyo@inorg.alcala.es
}

co-workers [7] employing ancillary chelating ligands which confer greater stability to these complexes and provide a facile route to cationic materials with potentially greater olefin affinity [8].

Our efforts have focused on employing cyclopentadienyl and imido groups as ancillary ligands to develop and study new tungsten alkylidene complexes. In this paper we describe the syntheses of new cyclopentadienyl imido halo derivatives of tungsten which are excellent starting materials for the preparation of alkylidene imido derivatives.

\section{Results and discussion}

\subsection{Syntheses and characterization of chloro imido pentamethylcyclopentadienyl complexes of tungsten}

A useful method to prepare cyclopentadienyl tungsten $(\mathrm{V})$ chlorides is the oxidation of low valent tungsten carbonyl compounds with $\mathrm{PCl}_{5}$ [9]. We recently reported [5] the synthesis of $\mathrm{WCp}^{*} \mathrm{Cl}_{4}[10] \mathbf{1}$ by oxidation 
of $\left[\mathrm{WCp} *(\mathrm{CO})_{2}\right]_{2}$ with an excess of $\mathrm{PCl}_{5}$ in toluene. The same compound can also be obtained by oxidation of WCp* $(\mathrm{CO})_{3} \mathrm{H}[11]$ with an excess of $\mathrm{PCl}_{5}$ in similar yields and shorter times.

Reaction of complex 1 with three equivalents of tert-butylamine and subsequent oxidation with half an equivalent of $\mathrm{PCl}_{5}$ lead to the reported complex WCp* $\left(\mathrm{N}^{t} \mathrm{Bu}\right) \mathrm{Cl}_{3}$ [5] 2. In this reaction two excess equivalents of the amine are used to neutralize the $\mathrm{HCl}$ formed during the reaction. However, the synthesis of the arylimido complex WCp* $\left(N-2,6-\left(\mathrm{Me}_{2}\right)-\mathrm{C}_{6} \mathrm{H}_{3}\right) \mathrm{Cl}_{2} 3$ requires the addition of a more basic amine [12] like triethylamine. Therefore, we isolated 3 by reaction of 1 with one equivalent of $2,6-\left(\mathrm{Me}_{2}\right)-\mathrm{C}_{6} \mathrm{H}_{3}-\mathrm{NH}_{2}$ and two equivalents of $\mathrm{NEt}_{3}$ in toluene.

Complex 3 which was isolated as a brown solid in high yield is an air and moisture sensitive compound, soluble in aromatic hydrocarbons and chlorinated solvents, which was characterized by elemental analysis and on the basis of its reactivity.

Oxidation of 3 with half an equivalent of $\mathrm{PCl}_{5}$ in toluene at $70^{\circ} \mathrm{C}$ gave to the tungsten(VI) imido complex WCp* $\left(N-2,6-\left(\mathrm{Me}_{2}\right)-\mathrm{C}_{6} \mathrm{H}_{3}\right) \mathrm{Cl}_{3} 4$ as thermally stable but air and moisture sensitive microcrystalline yellow solid in good yield, which can be stored under argon for months without decomposition. Compound $\mathbf{4}$ is soluble in aromatic hydrocarbons and partially soluble in hot hexane from which it can be recrystallized.

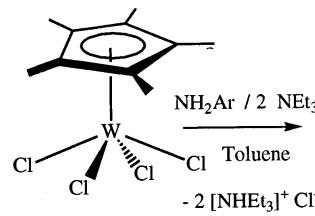

1

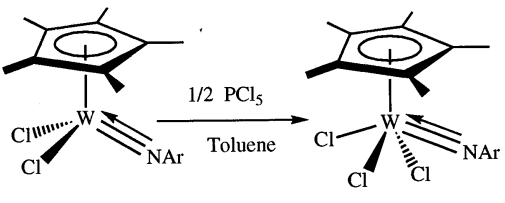

3

4

The ${ }^{1} \mathrm{H}$ - and ${ }^{13} \mathrm{C}-\mathrm{NMR}$ data for 4 (see Section 4) are consistent with the pseudo-square-pyramidal coordination found $[10,12]$ for related compounds, where the three chlorine atoms and the nitrogen atom of the arylimido group occupy the four square planar positions.

\subsection{Alkylation of $W C p^{*}(N R) C l_{3},\left(R={ }^{t} B u\right.$, 2,6- $\left.\left(\mathrm{Me}_{2}\right)-\mathrm{C}_{6} \mathrm{H}_{3}\right)$}

\subsubsection{Methyl derivatives}

Alkylation of 2 with 1.5 equivalents of $\mathrm{ZnMe}_{2}$ in hexane at room temperature gave $\mathbf{5}$ which was isolated in higher yield $(70-80 \%)$ than that reported using $\mathrm{MeMgCl}$ as alkylating agent [5]. Similarly, complex 4 reacted with 1.5 equivalents of $\mathrm{ZnMe}_{2}$ in hexane to give the trimethyl derivative $\mathrm{WCp} *\left(N-2,6-\left(\mathrm{Me}_{2}\right)-\mathrm{C}_{6} \mathrm{H}_{3}\right) \mathrm{Me}_{3}$ $\mathbf{6}$, which was isolated as a very air and moisture sensitive yellow crystalline solid. Complexes $\mathbf{5}$ and $\mathbf{6}$ are soluble in aromatic and saturated hydrocarbons.

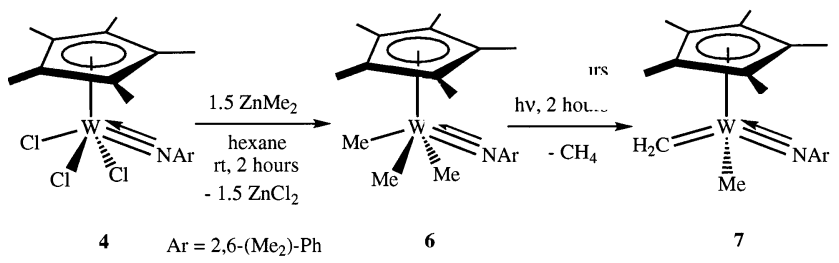

While looking for the formation of new alkylidene imido complexes, we studied their thermal and photochemical activation, with variable results. When a benzene- $\mathrm{d}_{6}$ solution of 5 was heated in an NMR tube at $100^{\circ} \mathrm{C}$ over $24 \mathrm{~h}$ no significant changes were observed; complete decomposition occurred when the temperature was raised to $150^{\circ} \mathrm{C}$ and maintained over $12 \mathrm{~h}$. Evolution of methane was detected by ${ }^{1} \mathrm{H}-\mathrm{NMR}$ spectroscopy but it was not possible to characterize any organometallic product.

Thermal activation of complex $\mathbf{6}$ was also monitored by ${ }^{1} \mathrm{H}-\mathrm{NMR}$ spectroscopy. Starting from a pure sample of $\mathbf{6}$, no changes were observed until the temperature reached $120^{\circ} \mathrm{C}$ and was maintained for $48 \mathrm{~h}$. The starting material disappeared and evolution of methane and ethylene were observed leaving a mixture of at least two organometallic species which could not be characterized. The ${ }^{1} \mathrm{H}-\mathrm{NMR}$ spectrum of this mixture showed signals due to $\mathrm{Cp}^{*}$ and imido ligands bonded to tungsten in both products and a signal due to a methyl group bonded to tungsten in one of them.

However exposure of a benzene- $d_{6}$ solution of 6 to sun-light for $3 \mathrm{~h}$ gave a solution ${ }^{1} \mathrm{H}-\mathrm{NMR}$ spectrum showing signals due to the starting complex along with two new doublets at $\delta=11.45\left(\mathrm{~d}, J_{\mathrm{HH}}=8.8 \mathrm{~Hz}, 1 \mathrm{H}\right)$ and $\delta=9.49\left(\mathrm{~d}, J_{\mathrm{HH}}=8.8 \mathrm{~Hz}, 1 \mathrm{H}\right)$ and one singlet at $\delta=0.78$, consistent with the formation of an alkylidene imido complex WCp* $\left(N-2,6-\left(\mathrm{Me}_{2}\right)-\mathrm{C}_{6} \mathrm{H}_{3}\right)\left(=\mathrm{CH}_{2}\right)(\mathrm{Me}) 7$ (Eq. $2)$. This compound could not be isolated because decomposition occured before the reaction was complete.

This observation led us to attempt the formation of potentially stable alkylidene imido complexes, using bulkier alkyl ligands such as benzyl and trimethylsilyl methyl.

\subsubsection{Benzylidene and trimethylsilylmethylidene imido derivatives}

Reaction of $\mathrm{WCp} *\left(\mathrm{~N}^{t} \mathrm{Bu}\right) \mathrm{Cl}_{3} 2$ with 1.5 equivalents of $\mathrm{MgBz}_{2}-(\text { thf })_{2}$ or two equivalents of $\mathrm{LiCH}_{2} \mathrm{SiMe}_{3}$ in hexane, at low temperature and in the absence of light yielded $\mathrm{WCp} *\left(\mathrm{~N}^{t} \mathrm{Bu}\right)(=\mathrm{CHPh})\left(\mathrm{CH}_{2} \mathrm{Ph}\right) \mathbf{8}$ and $\mathrm{WCp} *\left(\mathrm{~N}^{\mathrm{t}}-\right.$ $\left.\mathrm{Bu})(=\mathrm{CHSiMe})_{3}\right) \mathrm{Cl} \mathbf{9}$ as oily brown solids. Complexes $\mathbf{8}$ and 9 are air and moisture sensitive and must be manipulated in dry box. Both complexes are very soluble in all solvents commonly used.
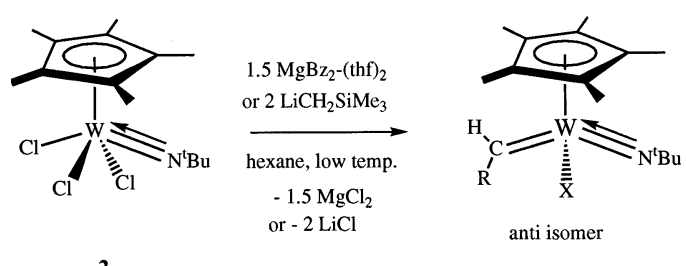

$\mathrm{R}=\mathrm{Ph}, \mathrm{X}=\mathrm{CH}_{2} \mathrm{Ph}(\mathbf{8})$ $\mathrm{R}=\mathrm{SiMe}_{3}, \mathrm{X}=\mathrm{Cl}(\mathbf{9})$ 
Table 1

Selected NMR spectral data for the alkylidene cyclopentadienyl imido complexes $\left(\mathrm{C}_{6} \mathrm{D}_{6}\right)$

\begin{tabular}{llll}
\hline Alkylidene complex & $\frac{=\mathrm{C} \underline{H \mathrm{R}}}{\delta} J_{\mathrm{HH}}(\mathrm{Hz})$ & $\frac{\mathrm{C} H \mathrm{R}}{\delta}$ & $\frac{\delta}{\delta}$
\end{tabular}

$\left.\mathrm{WCp} *\left(N-2,6-\mathrm{Me}_{2}\right)-\mathrm{C}_{6} \mathrm{H}_{3}\right)\left(=\mathrm{CH}_{2}\right) \mathrm{Me} \quad 11.45 \quad 8.8$

(7)

\begin{tabular}{|c|c|c|}
\hline & 9.49 & \\
\hline $\mathrm{VCp} *\left(\mathrm{~N}^{t} \mathrm{Bu}\right)(=\mathrm{CHPh})\left(\mathrm{CH}_{2} \mathrm{Ph}\right)(8$ & 10.24 & 246.7 \\
\hline $\mathrm{WCp} *\left(\mathrm{~N}^{t} \mathrm{Bu}\right)\left(=\mathrm{CHSiMe}_{3}\right) \mathrm{Cl}(\mathbf{9})$ & 10.63 & 249.1 \\
\hline
\end{tabular}

In these cases, the $\alpha$-hydrogen abstraction is a spontaneous process due to the bulkier alkyl ligands and it was not possible to isolate the trialkyl complexes even when the reactions were monitored at low temperature by NMR spectroscopy. In the second case, total alkylation was not possible even when an excess of the lithium agent was used, probably due to the steric demands of the bulkier trimethylsilylmethyl ligand.

The ${ }^{1} \mathrm{H}-\mathrm{NMR}$ spectra of $\mathbf{8}$ and $\mathbf{9}$ show the presence of only one isomer, identified as the anti isomer by NOE studies. The higher stability of this isomer is probably due to the preferred orientation of the alkylidene proton, instead of the more hindered alkyl group, pointing toward the $\eta^{5}$-pentamethylcyclopentadienyl ring.

The spectra show singlets at $\delta=10.24$ and 10.63, respectively due to the alkylidene protons (Table 1). In complex 8, the two methylenic protons of the benzyl ligand are non-equivalent due to the chiral character of the metal center and give two doublets at $\delta=2.62$ (d, $\left.J_{\mathrm{HH}}=10.8 \mathrm{~Hz}, 1 \mathrm{H}\right)$ and $\delta=2.33\left(\mathrm{~d}, J_{\mathrm{HH}}=10.8 \mathrm{~Hz}, 1 \mathrm{H}\right)$. The remaining signals are as expected and their chemical shift values are displayed in the experimental section. Analogously the alkylidene carbons show a signal in the ${ }^{13} \mathrm{C}-\mathrm{NMR}$ spectra at 246.7 and $249.1 \mathrm{ppm}$ for 8 and $\mathbf{9}$, respectively.

On the basis of the spectroscopic data and after comparison with similar complexes described in the literature [13] we proposed a three legged piano-stool structure whose apex is occupied by the $\eta^{5}$-pentamethylcyclopentadienyl ring for these alkylidene imido derivatives.

When the same reactions were carried out at room temperature and manipulated out of the dry box in the presence of sun-light, new products, proposed to be $\mathrm{WCp} *\left(\mathrm{~N}^{t} \mathrm{Bu}\right)(=\mathrm{CHPh})(\mathrm{OH})$ and $\mathrm{WCp} *\left(\mathrm{~N}^{t} \mathrm{Bu}\right)(=\mathrm{CHSi}-$ $\left.\mathrm{Me}_{3}\right)(\mathrm{OH})$, were formed [14]. We were not able to isolate these complexes which always appear in the reaction mixture together with complexes $\mathbf{8}$ and $\mathbf{9}$, respectively.

This observation led us to study the selective hydrolysis of complex 8. Reaction of $\mathbf{8}$ with one equivalent of deoxygenated water in $n$-hexane gave the oxo complex
WCp* $\left(\mathrm{N}^{t} \mathrm{Bu}\right)(\mathrm{O})\left(\mathrm{CH}_{2} \mathrm{Ph}\right) \mathbf{1 0}$ and toluene. Complex 10 was isolated as a microcrystalline yellow solid in quantitative yield and characterized by elemental analysis and ${ }^{1} \mathrm{H}-,{ }^{13} \mathrm{C}-\mathrm{NMR}$ spectroscopy. The two methylenic protons appear as two doublets (see Section 4). Complex 10 must therefore present a structure similar to the alkylidene imido derivatives already discussed.

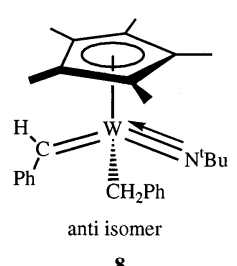

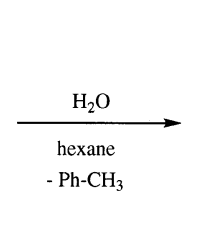

The hydrolysis of $\mathbf{8}$ with 0.5 and 1.5 equivalents of water gave a mixture containing complex $\mathbf{1 0}$ together with other uncharacterized organometallic products.

\section{Conclusions}

Synthesis of new alkylidene cyclopentadienyl imido tungsten (VI) complexes has been achieved through $\alpha$-hydrogen abstraction processes from suitable alkyl derivatives. These alkylidene complexes present a chiral tungsten center and are very stable due to the presence of cyclopentadienyl and imido groups as ancillary ligands.

These complexes should be suitable starting materials for cationic derivatives with potentially greater catalytic activity.

\section{Experimental details}

All manipulations were performed under an inert atmosphere of argon using standard Schlenck techniques or a dry box. Solvents used were previously dried and freshly distilled under argon: tetrahydrofuran from sodium benzophenone ketyl; toluene from sodium; hexane from sodium-potassium; $\mathrm{CCl}_{4}$ over calcium chloride. Unless otherwise stated, reagents were obtained from commercial sources and used as received. Amines, $\mathrm{NH}_{2}^{\mathrm{t}} \mathrm{Bu}$ and $\mathrm{NH}_{2}\left(2,6-\left(\mathrm{Me}_{2}\right)-\mathrm{C}_{6} \mathrm{H}_{3}\right)$ were purchased from commercial sources, dried over sodium hydride and then purified by distillation under argon before use. Reagents $\mathrm{MgBz}_{2}-(\text { thf })_{2}$ [15] and $\mathrm{LiCH}_{2} \mathrm{SiMe}_{3}$ [16] were prepared according to literature methods.

IR spectra were recorded in Nujol mulls between CsI pellets, over the range $4000-200 \mathrm{~cm}^{-1}$ on a PerkinElmer 583 spectrophotometer. ${ }^{1} \mathrm{H}$ - and ${ }^{13} \mathrm{C}$-NMR spectra were recorded on a Varian Unity VXR-300 or Varian Unity 500 Plus instruments. Chemical shifts, in 
ppm were measured relative to residual ${ }^{1} \mathrm{H}$ - and ${ }^{13} \mathrm{C}$ resonances in the benzene- $\mathrm{d}_{6}$ used as solvent: $7.15\left({ }^{1} \mathrm{H}\right)$ and $128.0\left({ }^{13} \mathrm{C}\right)$, and coupling constants are in $\mathrm{Hz} . \mathrm{C}, \mathrm{H}$ and $\mathrm{N}$ analysis were carried out with a Perkin-Elmer $240 \mathrm{C}$ and Hewlett-Packard 5988 A spectrometers.

\section{1. $\mathrm{WCp}^{*} \mathrm{Cl}_{4} \mathrm{1}$}

This compound was prepared following a method similar to that described by our research group [5] but using WCp*(CO $)_{3} \mathrm{H}$ instead of $\left[\mathrm{WCp} *(\mathrm{CO})_{2}\right]_{2} . \mathrm{PCl}_{5}$ $(5.17 \mathrm{~g}, 24.8 \mathrm{mmol})$ was slowly added to a solution of WCp* $(\mathrm{CO})_{3} \mathrm{H}(5.0 \mathrm{~g}, 12.4 \mathrm{mmol})$ in toluene $(50 \mathrm{ml})$ and the mixture was stirred at $70^{\circ} \mathrm{C}$ for $12 \mathrm{~h}$ to give an orange solid which was filtered, washed with methylene chloride, dried in vacuum and identified as complex $\mathbf{1}$ by elemental analysis and comparison of its IR spectrum with reported data [5].

\section{2. $W C p^{*}\left(\mathrm{~N}-2,6-\left(\mathrm{Me}_{2}\right)-\mathrm{C}_{6} \mathrm{H}_{3}\right) \mathrm{Cl}_{2} 3$}

A stoichiometric amount of freshly distilled 2,6$\left(\mathrm{Me}_{2}\right)-\mathrm{C}_{6} \mathrm{H}_{3}-\mathrm{NH}_{2}(0.43 \mathrm{ml}, 3.5 \mathrm{mmol})$ and two equivalents of $\mathrm{NEt}_{3}(0.97 \mathrm{ml}, 7.0 \mathrm{mmol})$ were added to a toluene $(50 \mathrm{ml})$ suspension of $1(1.6 \mathrm{~g}, 3.5 \mathrm{mmol})$ and the mixture was stirred for $24 \mathrm{~h}$ to give a brown suspension. The ammonium salt formed was filtered off and all volatile compounds were removed in vacuum yielding a brown oil. Recrystallization of the residue from n-hexane $(30 \mathrm{ml})$ yields $1.78 \mathrm{~g}(75 \%)$ of brown-yellow crystals of complex 3. IR (CsI, cm ${ }^{-1}$ ): 1377 (s), $1321(\mathrm{~m}), 1024$ (m), 777 (m), 730(w), 330 (m). Anal. calc. for $\mathrm{C}_{18} \mathrm{H}_{24} \mathrm{Cl}_{2} \mathrm{NW}$ : C, 42.38; $\mathrm{H}, 5.27 ; \mathrm{N}, 2.73$. Found: C, 42.19; H, 4.93; N, 2.71.

\section{3. $W C p^{*}\left(\mathrm{~N}-2,6-\left(\mathrm{Me}_{2}\right)-\mathrm{C}_{6} \mathrm{H}_{3}\right) \mathrm{Cl}_{3} 4$}

A toluene solution of WCp* $\left(N-2,6-\left(\mathrm{Me}_{2}\right)-\mathrm{C}_{6} \mathrm{H}_{3}\right) \mathrm{Cl}_{2}$ prepared by reacting $\mathrm{WCp}^{*} \mathrm{Cl}_{4}(1.42 \mathrm{~g}, 3.09 \mathrm{mmol})$ with the stoichiometric amount of 2,6- $\left(\mathrm{Me}_{2}\right)-\mathrm{C}_{6} \mathrm{H}_{3}-\mathrm{NH}_{2}$ $(0.38 \mathrm{ml}, 3.09 \mathrm{mmol})$ and two equivalents of $\mathrm{NEt}_{3}(0.85$ $\mathrm{ml}, 6,18 \mathrm{mmol})$ were treated with $\mathrm{PCl}_{5}(0.32 \mathrm{~g}, 1.54$ $\mathrm{mmol}$ ). The color of the solution changed from brown to yellow-orange and after stirring for $2 \mathrm{~h}$ at room temperature the insoluble solid was removed by filtration. The toluene solution was cooled to $-40^{\circ} \mathrm{C}$ to give yellow crystals of complex 4 (1.18 g, $2.16 \mathrm{mmol}, 70 \%)$. IR (CsI, cm ${ }^{-1}$ ): 1376 (s), 1301 (m), 1030 (m), 770 (m), 723(w), $302(\mathrm{~s}) .{ }^{1} \mathrm{H}-\mathrm{NMR}\left(\mathrm{C}_{6} \mathrm{D}_{6}\right): \delta 6.98(\mathrm{t}, 1 \mathrm{H}, 2,6-$ $\left.\mathrm{Me}_{2} \mathrm{C}_{6} H_{3}\right), 6.75$ (d, 2H, 2,6- $\left.\mathrm{Me}_{2} \mathrm{C}_{6} H_{3}\right), 2.73$ (s, 6H, 2,6- $\mathrm{Me}_{2} \mathrm{C}_{6} \mathrm{H}_{3}$ ), 2.05 (s, $15 \mathrm{H}, \mathrm{C}_{5} \mathrm{Me}_{5}$ ). ${ }^{13} \mathrm{C}\left\{{ }^{1} \mathrm{H}\right\}-\mathrm{NMR}$ $\left(\mathrm{C}_{6} \mathrm{D}_{6}\right): \delta 140.5\left(\mathrm{~s}, \mathrm{C}_{\mathrm{ipso}}\right), 131.1,128.8$ and $127.8\left(\mathrm{C}_{\text {aryl }}\right)$, $126.2\left(C_{5} \mathrm{Me}_{5}\right), 20.4\left(\mathrm{~s}, 2,6-M e_{2} \mathrm{C}_{6} \mathrm{H}_{3}\right), 12.9\left(\mathrm{~s}, \mathrm{C}_{5} M e_{5}\right)$. Anal. calc. for $\mathrm{C}_{18} \mathrm{H}_{24} \mathrm{Cl}_{3} \mathrm{NW}$ : C, 39.68; $\mathrm{H}, 4.77 ; \mathrm{N}$, 2.57. Found: C, 39.84; H, 4.32; N, 2.66.

\section{4. $W C p^{*}\left(N^{t} B u\right) M e_{3} 5$}

This compound was synthesized following a method similar to that described by our research group [5] but using $\mathrm{ZnMe}_{2}$ instead $\mathrm{MgClMe}$ as the alkylating agent. A $2.0 \mathrm{M}$ solution of $\mathrm{ZnMe}_{2}$ in toluene $(1.81 \mathrm{ml}, 3.63$ $\mathrm{mmol}$ ) was added dropwise at room temperature to a solution of $2(1.2 \mathrm{~g}, 2.42 \mathrm{mmol})$ in hexane. The mixture was stirred over a $2 \mathrm{~h}$ period and then was warmed to room temperature. The suspension was filtered and the yellow solution was concentrated under vacuum to $\approx 5$ $\mathrm{ml}$ and cooled to $-40^{\circ} \mathrm{C}$ affording $\mathbf{5}$ as a crystalline solid in $70 \%$ yield.

\section{5. $W C p^{*}\left(N-2,6-\left(M e_{2}\right)-C_{6} H_{3}\right) M e_{3} 6$}

A 2.0 M solution of $\mathrm{ZnMe}_{2}$ in toluene $(0.61 \mathrm{ml}, 1.2$ $\mathrm{mmol}$ ) was added dropwise at room temperature to a solution of $4(0.44 \mathrm{~g}, 0.8 \mathrm{mmol})$ in hexane $(30 \mathrm{ml})$. The mixture was stirred over a $2 \mathrm{~h}$ period. The suspension was filtered to separate the $\mathrm{ZnCl}_{2}$ formed and the resulting yellow solution was concentrated under vacuum to $\approx 5 \mathrm{ml}$ and cooled to $-40^{\circ} \mathrm{C}$ to give $6(0.27 \mathrm{~g}$, $70 \%$ as a yellow crystalline solid. IR (CsI, $\left.\mathrm{cm}^{-1}\right): 1376$ (s), 1320 (m), 1023 (m), 768 (m), 723(w). ${ }^{1} \mathrm{H}-\mathrm{NMR}$ $\left(\mathrm{C}_{6} \mathrm{D}_{6}\right): \delta 6.82\left(\mathrm{~m}, 3 \mathrm{H}, \mathrm{H}_{\text {aryl }}\right), 2.40(\mathrm{~s}, 6 \mathrm{H}, 2,6-$ $\left.M e_{2} \mathrm{C}_{6} \mathrm{H}_{3}\right), 1.55$ (s, $\left.15 \mathrm{H}, \mathrm{C}_{5} \mathrm{Me}_{5}\right), 1.08\left(\mathrm{~s}, 6 \mathrm{H}, 2-\mathrm{CH}_{3}\right.$ ), $0.52\left(\mathrm{~s}, 3 \mathrm{H},-\mathrm{CH}_{3}\right) \cdot{ }^{13} \mathrm{C}\left\{{ }^{1} \mathrm{H}\right\}-\mathrm{NMR}\left(\mathrm{C}_{6} \mathrm{D}_{6}\right): \delta 140.3(\mathrm{~s}$, $\left.\mathrm{C}_{\text {ipso }}\right), 134.6,128.2,124.4\left(\mathrm{C}_{\text {aryl }}\right), 110.2\left(\mathrm{~s}, C_{5} \mathrm{Me}_{5}\right), 30.1$ $\left(\mathrm{s}, 2,6-\mathrm{Me}_{2} \mathrm{C}_{6} \mathrm{H}_{3}\right), 26.8\left(\mathrm{~s}, 2-\mathrm{CH}_{3}\right), 20.0\left(\mathrm{~s},-\mathrm{CH}_{3}\right), 10.6$ (s, $\mathrm{C}_{5} M e_{5}$ ). Anal. calc. for $\mathrm{C}_{21} \mathrm{H}_{33} \mathrm{NW}: \mathrm{C}, 52.19 ; \mathrm{H}$, 6.83 ; N, 2.89. Found: C, 51.76; H, 6.53; N, 2.59.

\subsection{Observation of \\ $W C p^{*}\left(\mathrm{~N}-2,6-\left(\mathrm{Me}_{2}\right)-\mathrm{C}_{6} \mathrm{H}_{3}\right)\left(=\mathrm{CH}_{2}\right) \mathrm{Me} 7$}

A sealed NMR tube containing a solution of $6(0.015$ $\mathrm{g}, 0.03 \mathrm{mmol}$ ) in benzene- $\mathrm{d}_{6}$ was exposed to sun-light for a $3 \mathrm{~h}$ period. After that time the sample was monitored by ${ }^{1} \mathrm{H}-\mathrm{NMR}$ spectroscopy showing the presence of complex 7 in the reaction mixture. ${ }^{1} \mathrm{H}-\mathrm{NMR}$ $\left(\mathrm{C}_{6} \mathrm{D}_{6}\right): \delta 11.45\left(\mathrm{~d}, 1 \mathrm{H}, J_{\mathrm{HH}}=8.8 \mathrm{~Hz},=\mathrm{CH} H^{\prime}\right), 9.49(\mathrm{~d}$, $\left.1 \mathrm{H}, J_{\mathrm{HH}}=8.8 \mathrm{~Hz},=\mathrm{CHH}^{\prime}\right), 6.83\left(\mathrm{~m}, 3 \mathrm{H}, \mathrm{H}_{\mathrm{aryl}}\right), 2.48(\mathrm{~s}$, $\left.6 \mathrm{H}, 2,6-M e_{2} \mathrm{C}_{6} \mathrm{H}_{3}\right), 1.71\left(\mathrm{~s}, 15 \mathrm{H}, \mathrm{C}_{5} \mathrm{Me}_{5}\right), 0.78$ (s, $3 \mathrm{H}$, $\left.-\mathrm{CH}_{3}\right)$.

\section{7. $W C p^{*}\left(N^{t} B u\right)(=C H P h)\left(C H_{2} P h\right) \boldsymbol{8}$}

A solution of $\mathrm{MgBz}_{2}-(\mathrm{thf})_{2}(0.56 \mathrm{~g}, 1.59 \mathrm{mmol})$ in toluene $(20 \mathrm{ml})$ was added dropwise at $-78^{\circ} \mathrm{C}$ to a suspension of $2(0.5 \mathrm{~g}, 1.0 \mathrm{mmol})$ in hexane $(20 \mathrm{ml})$, in the absence of the sun-light. The mixture was stirred over a $4 \mathrm{~h}$ period and then was warmed to room temperature. The suspension was filtered inside a dry box to separate the $\mathrm{MgCl}_{2}$ formed and volatiles were removed from the resulting brown solution under vac- 
uum to afford an oily brown solid which was identified as complex $8(0.51 \mathrm{~g}, 90 \%) .{ }^{1} \mathrm{H}-\mathrm{NMR}\left(\mathrm{C}_{6} \mathrm{D}_{6}\right): \delta 10.2(\mathrm{~s}$, $1 \mathrm{H}, \mathrm{CHPh}), 6.8-7.5\left(\mathrm{~m}, \mathrm{H}_{\text {aryl }}\right), 2.62\left(\mathrm{~d}, 1 \mathrm{H}, J_{\mathrm{HH}}=10.8\right.$ $\left.\mathrm{Hz},-\mathrm{CH} H^{\prime} \mathrm{Ph}\right), 2.35\left(\mathrm{~d}, 1 \mathrm{H}, J_{\mathrm{HH}}=10.8 \mathrm{~Hz},-\mathrm{CHH}^{\prime} \mathrm{Ph}\right)$, $1.76\left(\mathrm{~s}, 15 \mathrm{H}, \mathrm{C}_{5} \mathrm{Me}_{5}\right), 1.10\left(\mathrm{~s}, 9 \mathrm{H},-^{\mathrm{t}} \mathrm{Bu}\right) .{ }^{13} \mathrm{C}\left\{{ }^{1} \mathrm{H}\right\}-\mathrm{NMR}$ $\left(\mathrm{C}_{6} \mathrm{D}_{6}, \mathrm{C}_{\text {aryl }}\right.$ resonances are not listed $): \delta 246.7(\mathrm{~s},=C \mathrm{HPh})$, $110.3\left(\mathrm{~s}, \mathrm{C}_{5} \mathrm{Me}_{5}\right), 67.9\left(\mathrm{~s},-\mathrm{C}\left(\mathrm{CH}_{3}\right)_{3}\right), 38.2\left(\mathrm{~s},-\mathrm{C}\left(\mathrm{CH}_{3}\right)_{3}\right)$, $31.4\left(\mathrm{~s},-\mathrm{CH}_{2} \mathrm{Ph}\right), 11.3\left(\mathrm{~s}, \mathrm{C}_{5} M e_{5}\right)$. Anal. calc. for $\mathrm{C}_{28} \mathrm{H}_{37} \mathrm{NW}$ : C, 58.68; H, 5.76; N, 2.43. Found: C, 59.87; $\mathrm{H}, 6.54 ; \mathrm{N}, .2 .15$.

\section{8. $\mathrm{WCp}^{*}\left(\mathrm{~N}^{t} \mathrm{Bu}\right)\left(=\mathrm{CHSiMe}_{3}\right) \mathrm{Cl} 9$}

A suspension of $2(0.5 \mathrm{~g}, 1.0 \mathrm{mmol})$ in $\mathrm{n}$-hexane $(20$ $\mathrm{ml}$ ) was cooled to approximately $-78^{\circ} \mathrm{C}$, then a solution of $\mathrm{LiCH}_{2} \mathrm{SiMe}_{3}(0.28 \mathrm{~g}, 3.02 \mathrm{mmol})$ in $\mathrm{n}$-hexane $(15 \mathrm{ml})$ was added dropwise in the absence of light and the mixture was allowed to reach room temperature slowly followed by stirring for $12 \mathrm{~h}$. After filtration, all volatile compounds were removed under vacuum leading to a oily brown solid identified as $9(0.48 \mathrm{~g}, 95 \%)$. ${ }^{1} \mathrm{H}-\mathrm{NMR}\left(\mathrm{C}_{6} \mathrm{D}_{6}\right): \delta 10.63$ $\left(\mathrm{s}, 1 \mathrm{H},=\mathrm{C} H \mathrm{SiMe}_{3}\right), 1.82\left(\mathrm{~s}, 15 \mathrm{H}, \mathrm{C}_{5} \mathrm{Me}_{5}\right), 1.35(\mathrm{~s}, 9 \mathrm{H}$, $\left.-\mathrm{C}\left(\mathrm{CH}_{3}\right)_{3}\right), 0.45\left(\mathrm{~s}, 9 \mathrm{H},=\mathrm{CHSi} M e_{3}\right),{ }^{13} \mathrm{C}\left\{{ }^{1} \mathrm{H}\right\}-\mathrm{NMR}$ $\left(\mathrm{C}_{6} \mathrm{D}_{6}\right): \delta 249.1\left(\mathrm{~s},=C \mathrm{HSiMe}_{3}\right), 113.5\left(\mathrm{~s}, C_{5} \mathrm{Me}_{5}\right), 69.2(\mathrm{~s}$, $\left.-C\left(\mathrm{CH}_{3}\right)_{3}\right), 31.8\left(\mathrm{~s},-\mathrm{C}\left(\mathrm{CH}_{3}\right)_{3}\right), 11.6\left(\mathrm{~s}, \mathrm{C}_{5} \mathrm{Me}_{5}\right), 3.2(\mathrm{~s}$, $\left.=\mathrm{CHSi} M e_{3}\right)$. Anal. calc. for $\mathrm{C}_{18} \mathrm{H}_{34} \mathrm{ClNW}: \mathrm{C}, 41.27 ; \mathrm{H}$, 6.49; N, 2.67. Found: C, 41.17; H, 7.03; N, 2.44.

\section{9. $W C p^{*}\left(\mathrm{~N}^{t} \mathrm{Bu}\right)(\mathrm{O})\left(\mathrm{CH}_{2} \mathrm{Ph}\right) \mathbf{1 0}$}

A toluene $(30 \mathrm{ml})$ solution of $8(0.15 \mathrm{~g}, 0.26 \mathrm{mmol})$ was treated with deoxygenated water $(4.7 \mu 1,0.26 \mathrm{mmol})$. After stirring for $12 \mathrm{~h}$, volatiles were removed from the resulting yellow-brown solution and the residue extracted into n-hexane. The yellow solution was concentrated and cooled to $-40^{\circ} \mathrm{C}$ affording complex 10 as a yellow mycrocrystalline solid $(0.12 \mathrm{~g}, 98 \%)$. ${ }^{1} \mathrm{H}-\mathrm{NMR}\left(\mathrm{C}_{6} \mathrm{D}_{6}\right): \delta$ $6.8-7.5\left(\mathrm{~m}, \mathrm{H}_{\mathrm{aryl}}\right), 2.97\left(\mathrm{~d}, 1 \mathrm{H}, J_{\mathrm{HH}}=12.2 \mathrm{~Hz},-\mathrm{CH} H^{\prime} \mathrm{Ph}\right)$, $2.54\left(\mathrm{~d}, 1 \mathrm{H}, J_{\mathrm{HH}}=12.2 \mathrm{~Hz},-\mathrm{C} H \mathrm{H}^{\prime} \mathrm{Ph}\right), 1.78(\mathrm{~s}, 15 \mathrm{H}$, $\left.\mathrm{C}_{5} \mathrm{Me}_{5}\right), 1.04\left(\mathrm{~s}, 9 \mathrm{H},-{ }^{\mathrm{t}} \mathrm{Bu}\right) .{ }^{13} \mathrm{C}\left\{{ }^{1} \mathrm{H}\right\}-\mathrm{NMR}\left(\mathrm{C}_{6} \mathrm{D}_{6}, \mathrm{C}_{\text {aryl }}\right.$ resonances are not listed): $\delta 115.3\left(\mathrm{~s}, C_{5} \mathrm{Me}_{5}\right), 66.9(\mathrm{~s}$, $\left.-C\left(\mathrm{CH}_{3}\right)_{3}\right), 39.2\left(\mathrm{~s},-\mathrm{C}\left(\mathrm{CH}_{3}\right)_{3}\right), 31.3\left(\mathrm{~s},-\mathrm{CH}_{2} \mathrm{Ph}\right), 10.8(\mathrm{~s}$, $\mathrm{C}_{5} M e_{5}$ ). Anal. calc. for $\mathrm{C}_{21} \mathrm{H}_{30} \mathrm{ONW}$ : C, 50.55; $\mathrm{H}, 6.41$; N, 2.80. Found: C, 50.38; H, 6.20; N, 2.64.

\section{Acknowledgements}

The authors acknowledge DGICYT (project PB920178-C) and Universidad de Alcalá (project UA 040/96) for financial support.

\section{References}

[1] W.A. Nugent, B.L. Haymore, Coord. Chem. Rev. 31 (1980) 123.

[2] (a) M.A. Andrews, H.D. Kaesz, J. Am. Chem. Soc. 99 (1977) 6763. (b) C.J. Schaverien, J.C. Dewan, R.R. Schrock, J. Am. Chem. Soc. 108 (1986) 2771. (c) J.S. Murdzek, R.R. Schrock, Organometallics 6 (1987) 1373. (d) R.R. Schrock, R.T. DePue, J. Feldman, K.B. Yap, D.C. Yang, W.M. Davis, L. Park, M. DiMare, M. Schofield, J. Anhaus, E. Walborsky, E. Evitt, C. Kruger, P. Betz, Organometallics 9 (1990) 2262.

[3] (a) G.W. Parshall, W.A. Nugent, D.M.-T. Chan, W. Tam, Pure Appl. Chem. 12 (1985) 1809. (b) R. Breslow, R.Q. Kluttz, P.L. Khanna, Tetrahedron Lett. 35 (1979) 3273. (c) E. Herranz, S.A. Biller, K.B. Sharpless, J. Am. Chem. Soc. 100 (1978) 3596. (d) D.W. Patrick, L.K. Truesdale, S.A. Biller, K.B. Sharpless, J. Org. Chem. 13 (1978) 2628. (e) T.-L. Ho, M. Henninger, G.A. Olah, Synthesis (1976) 815.

[4] (a) M.L.H. Green, P.C. Konidaris, P. Mountford, S.J. Simpson, J. Chem. Soc. Chem. Commun. (1992) 256. (b) U. Radius, J. Sundermeyer, Chem. Ber. 125 (1992) 2183. (c) J. Sundermeyer, U. Radius, C. Burschka, Chem. Ber. 125 (1992) 2379.

[5] P. Gómez-Sal, I. Jiménez, A. Martín, T. Pedraz, P. Royo, A. Selles, A. Vázquez de Miguel, Inorg. Chim. Acta 273 (1998) 270.

[6] (a) L.K. Johnson, R.H. Grubbs, J.W. Ziller, J. Am. Chem. Soc. 115 (1993) 8130. (b) L.K. Johnson, S.C. Virgil, R.H. Grubbs, J. Am. Chem. Soc. 112 (1990) 5384. (c) R.R. Schrock, R.T. DePue, J. Feldman, K.B. Yap, D.C. Yang, W.M. Davis, L. Park, M. DiMare, M. Schofield, J. Anhaus, E. Walborsky, E. Evitt, C. Kruger, P. Betz, Organometallics 9 (1990) 2262. (d) R.R. Schrock, R.T. DePue, J. Feldman, C.J. Schaverien, J.C. Dewan, A. H. Liu, J. Am. Chem. Soc. 110 (1988) 1423. (e) J. Kress, J.A. Osborn, R.M.R. Greene, K.J. Ivin, J.J. Rooney, J. Am. Chem. Soc. 109 (1987) 899.

[7] (a) A.S. Gamble, J.M. Boncella, Organometallics 12 (1993) 2814. (b) L.L. Blosch, A.S. Gamble, K. Abboud, J.M. Boncella, Organometallics 11 (1992) 2342. (c) L.L. Blosch, K. Abboud, J.M. Boncella, J. Am. Chem. Soc. 113 (1991) 7066.

[8] W.M. Vaughan, K.A. Abboud, J.M. Boncella, Organometallics 14 (1995) 1567.

[9] (a) R.C. Murray, L. Blum, A.H. Liu, R.R. Schrock, Organometallics 4 (1985) 953. (b) A.H. Liu, R.C. Murray, J.C. Dewan, B.D. Santarsiero, R.R. Schrock, J. Am. Chem. Soc. 109 (1987) 4282.

[10] (a) Reference ([9]b). (b) Reference [5].

[11] G.J. Kubas, H.J. Wasserman, R.R. Ryan, Organometallics 4 (1985) 2012.

[12] K. Köhler, H.W. Roesky, A. Herzog, H. Gornitzka, A. Steiner, I. Usón, Inorg. Chem. 35 (1996) 1773.

[13] (a) S.F. Pedersen and R.R. Schrock, J. Am. Chem. Soc. 104 (1982) 7483. (b) M.S. Rau, C.M. Kretz, G.L. Geoffroy, A.L. Rheingold, Organometallics 12 (1993) 3447.

[14] This formulation is proposed on the basis of the signals found in the ${ }^{1} \mathrm{H}-\mathrm{NMR}$ spectra of these mixtures. These spectra show for these complexes a signal due to the alkylidene proton at $\delta=$ 11.04 and $\delta=11.21$ and a singlet at $\delta=4.05$ and $\delta=4.01$ (1:1 respect to the alkylidene proton), assigned to the proton of the hydroxide group.

[15] R.R. Schrock, J. Organomet. Chem. 122 (1976) 209.

[16] C. Tessiers-Youngs, O.T. Beachley Jr., Inorg. Synth. 24 (1986) 95. 